University of Nebraska - Lincoln

DigitalCommons@University of Nebraska - Lincoln

Journal for the Advancement of Developing

Economies

Economics Department

2014

Determinants of Non-oil Export and Economic Growth in Nigeria: An Application of the Bound Test Approach

\author{
Samson Adeniyi Aladejare \\ Federal University Wukari \\ Abdulwahab Saidi \\ Federal University Wukari
}

Follow this and additional works at: https://digitalcommons.unl.edu/jade

Part of the Econometrics Commons, Growth and Development Commons, International Economics Commons, Political Economy Commons, Public Economics Commons, and the Regional Economics Commons

Adeniyi Aladejare, Samson and Saidi, Abdulwahab, "Determinants of Non-oil Export and Economic Growth in Nigeria: An Application of the Bound Test Approach" (2014). Journal for the Advancement of Developing Economies. 4.

https://digitalcommons.unl.edu/jade/4

This Article is brought to you for free and open access by the Economics Department at DigitalCommons@University of Nebraska - Lincoln. It has been accepted for inclusion in Journal for the Advancement of Developing Economies by an authorized administrator of DigitalCommons@University of Nebraska - Lincoln. 


\title{
Determinants of Non-Oil Export and Economic Growth in Nigeria: An Application of the Bound Test Approach
}

\author{
Samson Adeniyi Aladejare, Abdulwahab Saidi \\ Federal University Wukari
}

\begin{abstract}
The effects of the recent global economic crises on Nigeria's economy have reaffirmed the urgent need for economic diversification in the country. Although no country is immune to such global crises, the over reliance on oil export revenue by Nigeria expose her economy excessively to external shocks. Therefore, this research examines the impact of aggregate non-oil sector and its determinant on economic growth. The bound test approach was explored to examine the long and short run effects of the non-oil export and its ensuing determinants. The result reveals a significant effect of non-oil export on economic growth in both the long and short run. Policies aimed at boosting the level and significance of the nonoil export were proposed.
\end{abstract}

Keywords: Consumer Price Index, Economic growth, Real Exchange Rate, Non-oil Export, Real Interest Rate.

\section{INTRODUCTION}

It is undisputable that Nigeria is a country naturally endowed with various kinds of resources to place her amongst the top emerging economies of the world. Unfortunately, the nation has not adequately utilized and benefited from the economic prosperity expected of a nation so richly blessed. Nigeria is a country believed to be too rich to be poor. Ironically, global economic indices from reputable international organizations have consistently categorized Nigeria as an economically backward state. For instance, in 2005, the UNDP human development index ranked Nigeria as 164th and 141st among 197 nations with low per capital income and "low quality of life" respectively (World Bank Development report, 2010).

However, a glance at the Nigerian economy from its export perspective shows that export is disaggregated into two goods: oil and non-oil exports. These are the major sources of her foreign exchange earnings (Mustapha 2010). Nigeria's economy has been a mono-product economy ever since the exploration of crude oil started in the 1970s. A closer examination of Central Bank of Nigeria (CBN) Annual report 2007 shows the dominance of oil as the major source of export earnings in the Nigerian economy. Oil accounts for over 90 percent total of export in Nigeria, while non-oil account for less than 10 percent totals of export. Obviously, since the post- independence era, the growth of Nigeria's non-oil export has been sluggish - falling from about $40 \%$ in 1979 to $5 \%$ in 2010 (John and Ogege 2010). Although many factors may have combined in explaining this general adverse development, the trade policy of the country (which is mainly skewed towards oil) has frequently been seen as a responsible factor. 
Over the years, Nigeria has applied several measures of trade protections as a means of consolidating her trading position. Nigeria adopted import substitution trade strategy immediately after independence and export promotion Strategy was later ushered in as part of the structural adjustment program. Through non-oil export promotion for instance, Nigeria can manage her resources to create enough wealth and improve the quality of the economy vis-à-vis standard of living and also enhance her global economic rating. An appraisal of Nigeria's export promotion policy indicates that there is need to review aspects relating to non-oil export so as to harness the vast potential hitherto largely under-utilized in that critical sector (Ezike and Ogege 2012). Furthermore, a well-developed export sector will provide employment opportunity for the people with the attendant reduction in social cost of unemployment. Earnings from non-oil export will reduce the strains on the balance of payment position and even improve it. A rewarding export drive can turn a hitherto underdeveloped economy into a prosperous economy. Export help in increasing the level of aggregate economic activities through it multiplier effects on the level of national income. (Usman 2010). Income earned through non-oil exporting will help in increasing the level of demand within the economy.

Therefore, the overall success of any strategy to increase the volume of non-oil export commodities will depend on, among others; the knowledge of what factors constraints export growth and the responsiveness of the exporters to changes in both price and non-price conditions (Ghura and Grannes 1994, Lukonga 1994, Okoh and Inono 2010). The understanding of the responsiveness of these non-oil export commodities to change in price and non-price factors is indispensable in formulating a sound export policy strategy. Where exports respond negatively to price, price change cannot bring about an increase in export volume; likewise, where export response is insensitive to supply, increased production cannot bring about an increase in export volume. Consequently, this study is an attempt at a better understanding of the direction and magnitude of response between aggregate non-oil export and its determinants and economic growth of Nigeria.

\section{LITERATURE REVIEW}

Various studies have been conducted to study the relationship between non-oil exports and economic growth in the literature. The result of these studies varies from one to the other; owing to the difference in methodologies and time frames as well as the variables captured in the models.

Usman (2010) carried out a research on non-oil export determinant and economic growth in Nigeria from 1988-2008 using multi-linear regression. The finding shows the existence of a positive relationship between GDP and Non-oil export, consumer price index and exchange rate. The study recommended that, since non-oil export was found to have positive effect on economic growth in Nigeria over the period of 1988-2008, it is believed that economic growth could be enriched and become efficient as government diversify its sources of export. Therefore, measures to further improve and increase the earning of the non-oil export are thought to be necessary for the country to experience sustainable development.

Muhammed (2004) carried out research on non-oil export growth and economic development in Saudi Arabia (1970-2003). The study adopted the use of three-stage least squares test. The result submits that Non-oil exports have positive sign in all the four dependent variables namely: export price, industrial production, population, with two of them highly significant and that at the same 
time, it is determined mainly by relative price and industrial production. Population growth was believed to have a negative impact on real per capita income. This was consistent with the fact that Saudi Arabia real GDP was growing at a slower rate than the rate of population growth. Exchange rate had the right sign, but appeared insignificant. The results of the study generally support that export contributes to economic development in Saudi Arabia. The study therefore recommended that, although Saudi Arabia is an oil rich country, which depends largely on exporting oil for the development process of the domestic economy. The role of non-oil export can also enhance investment, production, as well as economic development measure, via real per capita income.

Rasulbakshi and Mohseni (2010) studied the effect of non-oil export on economic growth in Iran using a Computable General Equilibrium (CGE) model. The result of their finding shows a positive relationship between non-oil export and economic growth. Among exportable nonoil sectors, industry and mining sector had the most effect on Iran's economic growth. Accordingly, a 30\% increase in non-oil export can grow national output by $19.96 \%$ and industry $64 \%$. The study thus concluded with emphasis on the result that shows that the industry and mining sector had the greatest effect on economic growth among all non-oil exportable sectors. The result opines that, paying attention to reinforcement of non-oil export with great emphasis on industrial export can facilitate and enhance Iran's economic growth. Monir and Ebraham (2010) carried out research survey on oil and non-oil export effect on economic growth in Iran (1973-2007). They used the time series and the method of Vector Auto regressive (VAR). Their finding show that real GDP responds positively to a shock in oil export, but this happened after 2 lags. Similarly, real GDP responds positively to a shock in non-oil export but happened with more increased lags. Their study opines that, in Iran, the main source of revenue of government is oil and the government expenditure is mainly based on the forecast of oil export revenue. The result also showed the positive effect of non-oil export on the economy in long run; submitting that good policies can improve government revenues and that change in policy making, requires comprehending and studying long-term development programs. Iran's economy was believed to have experienced growth in GDP during the study period, but this can be attributed to the high price of oil and stability of oil prices as at then. Thus, recommending that it would be better to apply the extra revenue caused by increase of oil price for development of non-oil export in order to sustain revenues.

Ekperiware (2009) carried out research on oil and non-oil FDI and economic growth in Nigeria from 1970-2008, adopting the Ordinary Least Square (OLS) methodology. The result of their finding shows that both Oil FDI and Non-Oil FDI are statistically significant at 5 percent degree of freedom. A one-unit change in Oil FDI will cause a 3.24 increase in the nation's economic growth and a one-unit change in Non-oil FDI causes a 3.5 unit increases in GDP. Submitting that, Non-oil FDI is more statistically significant and has more positive effect on the Nigerian economy. The study therefore recommends that, for Nigeria to generate more foreign investments, efforts should be made to attract FDI into the Non-oil FDI area. This is because from the empirical finding, beside the oil sector having higher trend in the economy, its contribution to economic growth is small compared to non-oil sector. This could be because the bulk of the work force of the country is located in this sector than the oil sector that is dominated by foreigners.

Kolawole and Okodua (2010) carried out a research on foreign direct investment, non-oil exports and economic growth in Nigeria using granger causality test. The study finding reveals that in the long-run, foreign direct investment affects economic growth positively in Nigeria. This positive effect on growth outcome, though significant when judged by the statistic, is unimpressively low 
as only about one percent change in economic growth will arise from a hundred percent change in Foreign Direct Investment inflows into the country within the context of the long-run horizon. The result also shows that FDI inflows in Nigeria contribute positively to non-oil export in the long-run. The result further shows that the responses of the variables to one standard deviation insinuations were on average, found to be dormant in the early stages of the out-of-sample forecast period; but all demonstrated pronounced responses after about 7 years into the forecast period. They therefore noted that policy shocks to Foreign Direct Investment, non-oil exports, and economic growth in Nigeria do not show immediate response in the desired direction. Consequently, policy makers need to be conscious of this lag in order to ensure appropriateness in the timing of policies in this regard.

Onayemi and Akintoye (2009), in their research on diversifying the productive base of Nigeria: an econometrics approach to the Assessment of non-oil export promotion strategies; used Vector Error Correction Model, Philip Perron unit root test, and tested co-integration with the use of Johansen (1988) techniques. Their finding revealed the relationship between non-oil export and the explanatory variables, showing that exchange rate lagged by one and exchange rate lagged by two are both statistically significant at one percent level of significant. Implying that exchange rate of previous year and year before significantly affect the volume of non-oil exports. Loan on export was found to be insignificant while its lagged value was significant at $10 \%$ and with a negative sign. The implication of this is that loan has not been a significant factor that influences the value of nonoil export. Also, institutional factors lagged by two was found to be significant at $10 \%$ significant level. The implication of this was that it took two years before the policy on export promotion began to have effect on non-oil export; thus, identifying serious time lag that call for serious attention.

Enoma and Mustafa (2010) studied the impact of financial sector reforms on non-oil export in Nigeria employing the use of multiple regression techniques. Their finding shows that the non- oil price has the expected sign and highly significant at one percent level of significance, money supply was equally significant at one percent. While interest rate and exchange rate were significant at five percent. Their conclusion and recommendation were that there exists a long run relationship between non-oil export supply and financial sector parameters, namely, money supply exchange rate and interest rate. This result conforms to the result of Iyiola (2001) and Enoma (2009).

Efobi and Osabuohien (2010), research on the promotion of non-oil export in Nigeria. The work used variance decomposition approach, vis-à-vis co-integration test and Augmented Dickey Fuller (ADF) as well as Phillip- Perron (PP) test. The result of the study indicates that there exists a longrun relationship between the non-oil export and agricultural credit guarantee scheme fund as well as political constraints in Nigeria. They revealed that in the long-run, agricultural credit guarantee scheme, food crops as well as livestock exhibits a positive impact on the non-oil export value of Nigeria. Agricultural credit guarantee scheme fund on cash crop and political constraints, have a long-run negative impact on non-oil export. The study recommends that since long-run explanatory variables are all elastic, their variations would bring about more than proportionate change in the level of non-oil exports. The important implication that can be inferred is that to significantly boost non-oil export in Nigeria, provision of credit facilities especially the revamping of the Agricultural Credit Scheme Fund (ACGSF) through its various sub-components will yield satisfactory outcome on non-oil exports. This finding is very germane given the need to diversify the export base of the nation especially as the current global economic crisis is taking its toll in the price of oil and gas products. 
Anthony and Somiara (2010), carried out a research on the impact of macroeconomic variables on non-oil export performance in Nigerian, from 1986-2010. The study used Ordinary Least Square technique (OLS). The result showed that exchange rate, government capital expenditure and government recurrent expenditure have impacted and contributed greatly to non-oil export. While the agricultural sector, manufacturing sub-sector and interest rate did not greatly impact and contribute to non-oil export during the period of the study. They therefore recommended that investment should be increased in non-oil export (agriculture and manufacturing sector) since the result shows that they are related to macroeconomics variables used except the interest rate.

Ezike and Ogege (2012), investigated Nigeria foreign trade policy and its impact on non-oil export. The study used both correlation analysis and least square techniques. Their finding shows that there is a negative relationship between trade policies and non-oil export in Nigeria. However, non-oil export has positive effect on economic growth in Nigeria; also exchange rate is positive and significant at $5 \%$ level of significance. They therefore recommend that a country that diversifies its export base stand a better chance of achieving economic growth. Thus, a trade policy that focuses mainly on a mono-product in this case crude petroleum is flawed and exposes the country to instability and external shocks incidental to the global oil market. Nigeria would therefore be betteroff if it makes effort to diversify its economy by encouraging production and exportation of nonoil products.

Usman and Salami (2009), investigated the contribution of Nigeria export-import bank towards non-oil export growth in Nigeria. The study used OLS method of estimation. The result of the study and available data suggest that non-oil exports performance during the study period remained less satisfactory. The study thus recommends that Nigeria export-import bank activities enhances and add value to quality and price of non-oil export in Nigeria, therefore activities of Nigeria exportimport bank should be encourage.

Okunu and Adeyemi (2007), researched on Non-Oil Export Development and Promotion as a Strategy for increasing Foreign Exchange Earnings in the Nigeria economy using OLS technique. From their finding, it was observed that the contribution of non-oil export during the first period of 1980 to 1994 was not impressive compared with the contribution of oil export during the same period. There was slight improvement in the performance of non-oil effort during the second period of 1995 to 2003 compared with contribution of oil export in the same period. The study thus recommends that; government should invest in agriculture i.e. cultivation of vast plots of land, for the farming of crops, in areas, where these crops thrive most and ensure adequate management/administration of the crops to ensure high revenue yield from agricultural production export. They also recommended that the government should try to develop the mining of solid minerals, which should entail the training of people for the activity of mining. The mineral output should be well-processed so as to meet international market standards.

\section{METHODOLOGY}

In this study, data will be collected on aggregate non-oil export value, exchange rate, Consumer Price Index as proxy for inflation, Real Interest Rate and Real Gross Domestic Product (RGDP) as proxy for economic growth from 1970 to 2012. Data on RGDP, Non-oil Export (NOEX), Real Exchange Rate (REXCH), Consumer Price Index (CPI) and Real Interest Rate (RINT) were sourced from the statistical bulletin of the Central Bank of Nigeria and the World Bank Data Base. 


\section{Estimation Technique}

The study method adopted in this work is the Auto-Regressive Distributed Lag (ARDL) bounds testing approach developed by Pesaran et al. (2001). The justification for the selection of this approach is based on the advantages of the ARDL for testing the existence of a cointegrating relationship either in the short-run or long-run. Pesaran et al. (2001) developed a new AutoRegressive Distributed Lag (ARDL) bounds testing approach for testing the existence of a cointegrating relationship.

The bound testing approach has certain econometric advantages in comparison to other single cointegration procedures (Engle and Granger, 1987; Johansen, 1988; Johansen and Juselius, 1990). First, endogeneity problems and inability to test hypotheses on the estimated coefficients in the long-run associated with the Engle-Granger (1987) method are avoided. Secondly, the long and short-run parameters of the model in question are estimated simultaneously. Thirdly, the econometric methodology is relieved of the burden of establishing the order of integration amongst the variables and of pre-testing for unit roots. The ARDL approach to testing for the existence of a long-run relationship between the variables in levels is applicable irrespective of whether the underlying regressors are purely $I(0)$, purely $I(1)$, or fractionally integrated. Finally, as argued in Narayan (2005), the small sample properties of the bounds testing approach are far superior to that of multivariate cointegration (Halicioglu, 2007). The approach, therefore, is a modification of the Auto-Regressive Distributed Lag (ARDL) framework while overcoming the inadequacies associated with the presence of a mixture of $I(0)$ and $I(1)$ regressors in a Johansen-type framework.

$$
{ }_{p} Z_{t}=\mu_{0}+\Psi_{t}+\sum_{i=1}^{p} \partial_{i} Z_{t-1}+\varepsilon_{t}, \quad t=1,2 \ldots \ldots \ldots, T
$$

Where: $\mu_{0}=$ vector of intercepts

The corresponding Vector Error Correction Model (VECM) for Eq. (1) is derived as:

$$
\Delta Z_{t}=\mu_{0}+\Psi_{t}+\gamma i Z_{t-1}+\sum_{i=1}^{p} \lambda i Z_{t-1}+\varepsilon_{t}
$$

Where; $\Delta$ represent the first difference operator, $\gamma$ and $\lambda$ represents vector matrices that contain the long-run multipliers and short-run dynamic coefficients of the VECM respectively. $\mathrm{Zt}$ is a vector of Xt and Yt variables respectively. Yt (RGDPt) is the regressand and $\mathrm{Xt}=(\mathrm{NOEXt}, \mathrm{REXCHt}$, CPIt, RINTt) is a vector matrix of a set of regressors. As a condition, Yt must be an I(1) variable, while Xt regressors can either be $\mathrm{I}(0)$ and $\mathrm{I}(1)$. et is a stochastic error term. Assuming unrestricted intercepts and no trends, Eq. (2) becomes an unrestricted error correction model (UECM) as:

$$
\Delta Z_{t}=\mu_{0}+\gamma i Z_{t-1}+\sum_{i=1}^{p} \lambda_{i} Z_{t-1}+\varepsilon_{t}
$$

Incorporating the variables of interest, the UECM of Eq. 3 becomes:

$$
\begin{aligned}
& \Delta R G D P_{i}=\alpha_{0}+\beta_{1} \operatorname{lnRGDP} P_{t-1}+\beta_{2} N O E X_{t-1}+\beta_{3} \operatorname{lnREXCH}_{t-1}+\beta_{4} C P I_{t-1}+\beta_{4} R I N T_{t-1}+ \\
& \sum_{i=0}^{p} \lambda_{1 i} \Delta \ln R G D P_{t-i}+\sum_{i=0}^{p} \lambda_{2 i} \Delta N O E X_{t-i}+\sum_{i=0}^{p} \lambda_{3 i} \Delta \operatorname{lnREXCH}_{t-i}+\sum_{i=0}^{p} \lambda_{4 i} \Delta C P I_{t-i}+ \\
& \sum_{i=1}^{p} \lambda_{5 i} \Delta R I N T_{t-i}+u_{t}
\end{aligned}
$$

Where: $\ln =$ logarithm function 
ARDL testing approach: The testing procedure of the ARDL bounds test is performed in three steps. First, OLS is applied to Eq. (4) to test for the existence of a cointegrating longrun relationship normalized on lnRGDPt based on the Wald test (F-statistics) for the joint significance of the lagged levels of the variables (i.e., $\mathrm{H} 0: \mathrm{B} 1=\mathrm{B} 2=\mathrm{B} 3=\mathrm{B} 4=\mathrm{B} 5=0)$ as against the alternative $(\mathrm{H} 1: \mathrm{B} 1 \neq$ $\mathrm{B} 2 \neq \mathrm{B} 3 \neq \mathrm{B} 4 \neq \mathrm{B} 5 \neq 0$ ). The computed $\mathrm{F}$-statistic is then compared with the non-standard critical bounds values as reported in Pesaran et al. (2001). The lower and upper bounds critical values assumes that the regressors are purely I(0), purely I(1), respectively. If the F-statistic is above the upper critical value, the null hypothesis of no long-run relationship can be rejected irrespective of the orders of integration for the time series. Conversely, if the test statistic falls below the lower critical value the null hypothesis cannot be rejected. Finally, if the statistic falls between the lower and upper critical values, the result is inconclusive. Once cointegration is established, the second step involves estimating the long-run ARDL model for lnRGDPt as:

$\ln R G D P_{t}=\alpha_{0}+\sum_{i=1}^{p} \beta_{1} \ln R G D P_{t-i}+\sum_{i=0}^{p} \beta_{2} N O E X_{t-i}+\sum_{i=0}^{p} \beta_{3} \ln R E X C H_{t-i}+$ $\sum_{i=0}^{p} \beta_{4} C P I_{t-i}+\sum_{i=0}^{p} \beta_{5} R I N T_{t-i}+u_{t}$

The final step involves estimating an Error Correction Model (ECM) as derived from Eq. 5 to obtain the short-run dynamic parameters as specified below:

$$
\begin{aligned}
& \Delta R G D P_{t}=\alpha_{0}+\sum_{i=1}^{p} \lambda_{1 i} \Delta \ln R G D P_{t-i}+\sum_{i=0}^{p} \lambda_{2 i} \Delta N O E X_{t-i}+\sum_{i=0}^{p} \lambda_{3 i} \Delta \ln R E X C H_{t-i}+ \\
& \sum_{i=0}^{p} \lambda_{4 i} \Delta C P I_{t-i}+\sum_{i=0}^{p} \lambda_{5 i} \Delta R I N T_{t-i}+\delta e c m_{t-1}+u_{t}
\end{aligned}
$$

Where:

ecm $m_{t-1}=$ the error correction mechanism lagged for one period $\delta=$ the coefficients for measuring speed of adjustment

\section{EMPERICAL RESULTS UNIT ROOTS TEST}

Before applying the ARDL bounds test, the stationarity properties of all variables were examined to ascertain their respective orders of integration. The rationale behind the unit roots test is to avoid spurious results due to the presence of an $I(2)$ series. The bounds test is based on the assumption that the variables are $I(0)$ or $I(1)$ series. The presence of an $I(2)$ series renders the computed $F$ Statistic invalid thereby crushing the ARDL procedure. Hence, pre-testing for unit roots remains pertinent to the analysis. The Augmented Dickey-Fuller (ADF) test was applied on each variable while the Phillips-Perron (PP) test was used for confirmatory analysis with the results presented in Table 1.

The result shows that all the variables are integrated of order one, i.e. I(1), after first differencing. Overall, both test report similar results with the exception of the PP test for lncpi showing the absence of stationarity. However, since this study's decision of stationarity depends on confirmation of at least one of the two test procedures adopted; we can therefore conclude based on the ADF test result for lncpi that the variable is integrated of order one. Thus, confirming the absence of an I(2) series, which indicates the suitability of the variables for the ARDL bounds test procedure. 
Table 1: Unit Root Test Result

\begin{tabular}{|c|c|c|c|c|}
\hline \multicolumn{3}{|c|}{ ADF TEST RESULT } & \multicolumn{2}{|c|}{ PP TEST RESULT } \\
\hline Variable & $1^{\text {st }}$ Difference & Remark & $1^{\text {st }}$ Difference & Remark \\
\hline lnrgdp & $-53.82656 * * *$ & $\mathrm{I}(1)$ & $-47.09903 * * *$ & $\mathrm{I}(1)$ \\
\hline lnnoex & $-6.305095 * * *$ & $\mathrm{I}(1)$ & $-9.924297 * * *$ & $\mathrm{I}(1)$ \\
\hline lncpi & $-2.705921^{*}$ & $\mathrm{I}(1)$ & -2.582946 & \\
\hline lnrexch & $-4.264789 * * *$ & $\mathrm{I}(1)$ & $-4.154946 * * *$ & $\mathrm{I}(1)$ \\
\hline rint & $-5.821255^{* * *}$ & $\mathrm{I}(1)$ & $-20.98862 * * *$ & $\mathrm{I}(1)$ \\
\hline
\end{tabular}

Source: Computed by Authors

Note: $*, * *, * * *$ represent significance level of $10 \%, 5 \%$ and $1 \%$ respectively

Bounds test for cointegration: In the first step of the ARDL testing procedure, Eq.4 is tested for a cointegrating long-run analysis with normalization on the log of real gross domestic product. To select the appropriate lag length for the first differenced variables, we adopted a general-to- specific approach using an unrestricted VAR by means of Akaike Information Criterion (AIC). For brevity, the results of the lag selection are not reported. However, a maximum of 2 lag was used; which is also assumed to be the maximum short run period for this study. As argued by Pesaran and Pesaran (1997), variables 'in first difference are of no direct interest' to the bounds cointegration test. Hence, any result that supports cointegration in at least one lag structure provides evidence for the existence of a long-run relationship.

Table 2: Bounds Test for Cointegration

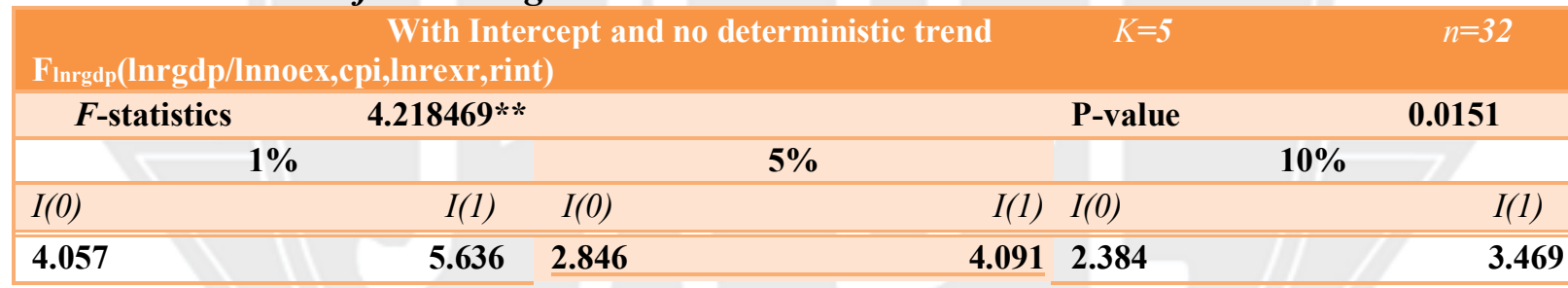

Source: Computed by Authors

Note: $\mathrm{k}=$ number of variables, $\mathrm{n}=$ number of observations, Critical values are exacted from Pesaran et. al. (2001), ** indicates significance at $5 \%$.

The calculated F-statistic together with the critical bounds values as reported in Table 2 shows that the calculated value of the F-statistic (i.e., 4.218469) for the bounds test for cointegration exceeds the upper bound critical value of 4.09 at $5 \%$ level. Thus, the null hypothesis of no cointegration is rejected, affirming the existence of a long-run cointegrating relationship. Based on the result in Table 2, we conclude that there is strong support for a long-run relationship between non-oil export and economic growth in the model for Nigeria. Following the establishment of the existence of cointegration, Eq. (5) and (6) were estimated to obtain long-run and short-run dynamic estimates using an ARDL $(1,0,0,0,0)$ selected based on AIC with results presented in Table 3 and 4 respectively.

Table 3 shows the long run impact of the regressors on the dependent variable. It can be deduced from the result that a $1 \%$ rise in non-oil export of Nigeria, would result in $2.8 \%$ rise in economic growth in the long run. This result shows that if the non-oil sector of Nigeria is properly managed and given due consideration like the oil sector, the sector has the potential to serve as the gateway 
to poverty reduction, rural transformation, employment generation, food security and improve nutritional health profile of the citizenry.

Table 3: Estimated Long Run Coefficients Using the ARDL Approach

\begin{tabular}{lllll}
\hline \multicolumn{2}{l}{ Dependent variable= Inrgdp } & \multicolumn{3}{l}{} \\
\hline Regressor & Coefficient & Standard Error & T-statistic & P-value \\
C Innoex & 813.578 & 0.337348 & 37.01459 & $0.0000^{* * *}$ \\
Cpi & 2.787 & 3.503670 & 3.503670 & $0.0017^{* * *}$ \\
Inrexch & 0.325 & 0.000450 & 11.08880 & $0.0000^{* * *}$ \\
Rint & -5.580 & 0.022397 & -3.823881 & $0.0007^{* * *}$ \\
& 0.019 & 0.000629 & 0.465104 & 0.6457 \\
\hline
\end{tabular}

Source: Computed by Authors

Note: $* * *$ indicate significance at $1 \%$, long-run coefficient estimates were obtained by normalizing on RGDP which is the dependent variable.

Furthermore, we also gathered from table 3 that in the long run; 1\% increase in Consumer Price Index (inflation) would yield about $0.33 \%$ rise in economic growth. Also, when real exchange rate rises by $1 \%$, economic growth tends to fall significantly by $5.6 \%$. This shows the impact of continuous exchange rate adjustment by the monetary authorities over a long period of time on the economy. The result also explains the relation between inflation, exchange rate and economic growth. That is: increase in inflation is accompanied by an inverse relation between exchange rate and economic growth. However, real interest rate seems not to have a long run significant impact on economic growth.

Table 4: Error Correction Representation for ARDL Model 6

\begin{tabular}{|c|c|c|c|c|}
\hline \multicolumn{5}{|c|}{ Dependent variable $=\Delta$ rgdp } \\
\hline \multirow{7}{*}{$\begin{array}{l}\text { Regressor C } \\
\Delta \text { noex(-1) } \\
\triangle \mathrm{Cpi}(-1) \\
\Delta \ln r e x c h(-1) \\
\Delta \operatorname{Rint}(-1) \mathrm{ECM}(-1)\end{array}$} & Coefficient & Standard Error & T-statistic & P-value \\
\hline & 0.015286 & 3453.173 & 0.900880 & 0.3774 \\
\hline & 1.11989E-06 & 0.082398 & 2.765975 & $0.0113 * * *$ \\
\hline & 0.005954 & 466.9476 & 2.594907 & $0.0165^{* *}$ \\
\hline & 0.003099 & 6893.237 & 0.091489 & 0.9279 \\
\hline & -0.00115 & 129.0913 & -1.805871 & $0.0846^{*}$ \\
\hline & -0.860097 & 0.382086 & -2.251055 & $0.0347 * *$ \\
\hline
\end{tabular}

$\mathrm{Ecm}=\Delta \operatorname{rgdp}+0.2279125 \mathrm{NOEX}+1211.686 \mathrm{CPI}+630.6577 \mathrm{REXCH}-233.1223 \mathrm{RINT}+3110.895 \mathrm{C}$

R-squared $=0.780405 \quad$ F-statistic $=13.03073$

Adj R-squared $=0.720515$ Prob(F-statistic $)=0.000003$

Durbin Watson stat $=1.485614$

Source: Computed by Authors

Note: $* * *, * * *$ indicate significance at $10 \%, 5 \%$ and $1 \%$ respectively.

Table 5: Diagnostic test

$X_{\text {norm }}^{2}=0.599957[0.740834] \quad X_{\text {seco }}^{2}(1)=1.720217[0.2045]$

$X_{\text {heterosk }}^{2}(1)=0.288752[0.9360]$

Note: $p$-value in parenthesis. Source: Computed by Authors 
Table 4 presents the short run relationship between the variables. It can be deduced from the table that the lagged by one values of: non-oil export, consumer price index and real interest rate, have significant impact on the current level of economic growth. A percentage increase in Non- oil exports of the previous year tends to have a positive infinitesimal impact on current level of economic growth. The obvious impact of the oil sector on the economy could be said to be responsible for this outcome. Furthermore, a percentage increase in CPI which proxy for inflation shows a $0.001 \%$ increase in the level of economic growth. This shows the acceptable level of increase in inflation that is desirable for growth in the economy. Although not significant; the table also shows that when real exchange rate rises by a percentage, the economy would grow by $0.003 \%$. The insignificance of the result could be due to the fact that its impact is mostly long term rather than short term. This is because it is the accumulated changes over time that impacts on economic growth and not a year's change. Real interest rate however happens to show an inverse relationship with economic growth. The result shows that a percentage increase in real interest rate would yield an infinitesimal fall of $0.001 \%$. The Error Correction Mechanism with the significant value of -0.86 means that about $86 \%$ distortion in the volume of non-oil export from the previous period is being corrected for in the current period for equilibrium to be restored. Thus, for a convergence back to the equilibrium state, it would take approximately a year and two months.
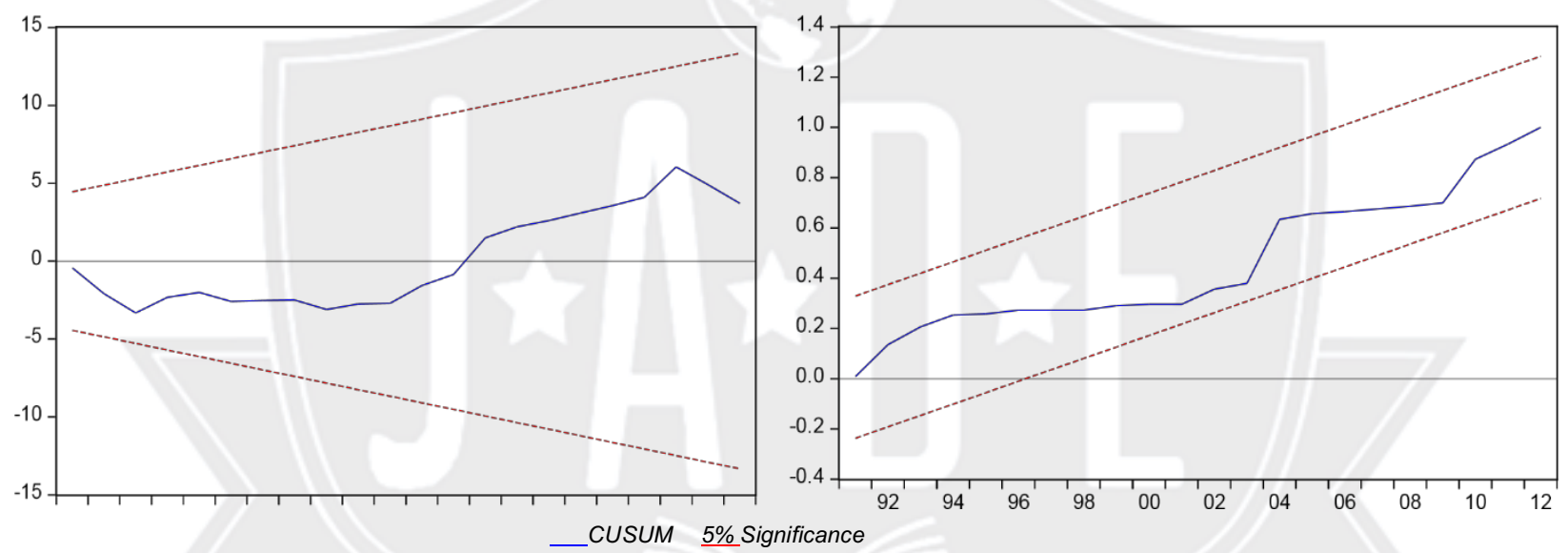

Figure 1: Plot of CUSUM and CUSUMQfor Coefficients Stability for ECM model

Table 5 gives the diagnostic test results conducted on the residual of the model. The normality test indicates acceptance of the Null hypothesis that residuals are normally distributed. Furthermore, the heteroskedasticity and serial correlation test also shows the acceptance of the Null hypothesis that residuals are not heteroskedastic nor serially correlated respectively. The adjusted $\mathrm{R}$ square for the short-run ARDL model is approximately $72 \%$ and satisfies the diagnostic tests for normality, serial correlation and heteroskedasticity.

Finally, to ensure that the models satisfy the stability test, we apply the cumulative sum of recursive residuals (CUSUM) and CUSUM of squares (CUSUMSQ) test proposed by Brown et al. (1975) to the residuals of the error-correction model. Figure 2 present plots of both CUSUM and CUSUMSQ test statistics that fall inside the critical bounds of 5\% significance. This implies that the estimated parameters are stable over the period 1980- 2012. 


\section{CONCLUSIONS AND RECOMMENDATIONS}

Based on the findings in this study which examined the impact of non-oil export on the growth of the Nigerian economy; the following conclusions were reached:

- If properly managed, the non-oil sector is well endowed with the capacity to improve the revenue base of the country and also reduce the level of unemployment of the country either in the short or long run.

- Long run adjustments of the real exchange rate by the monetary authorities have a significant inverse effect on the long run growth of the country. However, the impact in the short run turned out not significant. This shows that exchange rate impact on the economy is more of a long run phenomenon rather than short run.

- Interactions between inflation and exchange rate have significant impact on the growth of the economy. While inflation has both short and long run impact on the growth of the economy, exchange rate tends to be more of a long run phenomenon.

- Real interest rate is more of a short run phenomenon rather than long run. This is attributable to low investor confidence on returns to their investment, given the socio- political crises that are common with the country, as well as investment bottlenecks in the economy.

- Non-oil export has both short run and long run impact on the economy. A vindication of how very significant the sector is to the growth and development of the nation.

However, the following recommendations are being proposed:

- In order to maintain export competitiveness, the non-oil export of the country should be well packaged for international acceptance. The exchange rate, interest rate and inflation policy of the government should also be properly managed by monetary authorities. This is because of the chain relationship existing between these monetary variables with the non-oil sector, which together impact on the growth of the economy. A favorable interest rate would reduce the cost of production for producers in the non-oil sector likewise a favorable exchange rate would make their products compete favorably in the international market. Thus, leading to a growth in the economy.

- The non-oil sector should be developed to enhance the revenue base of the country as an alternative source of foreign receipt. The over reliance on oil proceeds by the economy which in recent times have proved not to be stable should serve as a "red light" for policymakers on the need to diversify the country's revenue sources. The non-oil sector therefore provides an alternative reliable source of income to oil revenue for the country. The non-oil sector therefore should be given equal parity with the oil sector because of its capacity to create more jobs for the economy and make the country self-reliant by serving as alternative and reliable source of income for the country.

- The non-oil sector has the capacity of generating huge employment for the high unemployed youths of the country. Unfortunately, Nigerian policymakers ever since the exploration of crude oil for commercial purposes in the 1970s, failed to explore this potential of the sector. It is therefore recommended that policymakers should tap into the potential of the sector with the view of generating small and medium scale employments, as well as initiate policies 
aimed at encouraging the expansion of existing firms in the sectors with the view to reduce the high unemployment problem of the country.

- Investment bottle-necks such as: high lending rates by banks, poor infrastructural facilities, and the attendant problems of insecurity which is gradually pervading every part of the country; thereby discouraging potential local and international investors in the sector should be addressed or drastically reduced. This would help guarantee investors' returns either in the short or long run on investment.

- Various components that make up the non-oil sectors such as: agriculture, mining, service, small and medium enterprises and manufacturing, should be given urgent developmental priority in terms of infrastructural provision because of their immediate returns to the economy. Also, proper exchange rate and inflation management policies aimed at improving performance of the non-oil sector as being adopted in recent times by the country's monetary authorities should be maintained. This would help alleviate some of the prolonged concerns of investors in the economy either in the short or long term. This would help boost investors' confidence by ensuring returns on investment and improved overall performance of the economy.

\section{REFERENCES}

Blecker, 1999, in Onayemi and Ishola, 2009. Diversifying the productive base of Nigeria, an Econometric Approach to the Assessment of Non-oil Export promotion strategies.

Enoma, A. and Isedu, M. 2011. The Impact of Financial Sector Reforms on Non-Oil Export in Nigeria, Journal of Economics Vol 2 (2) pp. 115-120

Ezike J.E and Ogege S (2012) Nigerian foreign trade policy: Its impact on non-oil exports Journal of Economics and International Finance Vol. 4(8), pp. 192-200.

Homayounifar, M and Rastegari, F. (2008), "Analysis of Economic-Political factors affecting Non-Oil Export of Iran", American-Eurasian Journal of Agriculture and Environmental Science, 2(supplement 1): 16-173.

lyoha, M. A. and Oriakhi, D. (2002), "Explaining African Economic Growth Performance: The Case of Nigeria." A Revised Interim Report on Nigerian Case Study prepared for the African Economic Research Consortium Research.

Olayiwola, K and Okodua, H. 2010. Foreign Direct Investment, Non-Oil Export, and the Economic Growth in Nigeria: a causality analysis, Ota Nigeria: Covenant Faith University.

Onayemi S.O., Ishola R.A. 2009. Diversifying the productive base of Nigeria, an econometric approach to the assessment of non-oil export promotion strategies.

Osuntogun, A., Edordu, C. C. and Oramah, B. 0. (1997), "Potentials for diversifying Nigeria's non-oil exports to non-traditional markets". AERC Research Paper 68, November.

Usman 0. A. and Salami A. 0. (2008) "The Contribution of Nigerian Export-Import (NEXIM) bank towards Export (non-oil) Growth in Nigeria (1990-2005)", International Business Management 2(3): 85-90.

Usman (2010). "Non-oil Export Determinants and Economic growth in Nigeria (19852008)": European Journal of Business and Management Sciences, Vol 3 No 3. Page 124 of 10 